\title{
C-type natriuretic peptide (CNP) effects in anterior pituitary cell lines: evidence for homologous desensitisation of CNP-stimulated cGMP accumulation in $\alpha \mathrm{T} 3-1$ gonadotroph-derived cells
}

\author{
R C Fowkes, W Forrest-Owen and C A McArdle \\ Division of Medicine, Department of Hospital Medicine, University of Bristol, Bristol Royal Infirmary, Marlborough Street, Bristol BS2 8HW, UK \\ (Requests for offprints should be addressed to R C Fowkes, who is now at St Bartholomew's and the Royal London School of Medicine and Dentistry, \\ Molecular Endocrinology Laboratory 1·4, 1st Floor Dominion House, St Bartholomew's Close, London EC1A 7BE, UK; Email: r.c.fowkes@mds.qmw.ac.uk)
}

\begin{abstract}
C-type natriuretic peptide (CNP), the third member of the natriuretic peptide family, has been found at its highest tissue concentrations in the anterior pituitary, where it is localised in gonadotrophs. Its specific guanylyl cyclasecontaining receptor, GC-B, is also expressed on several anterior pituitary cell types, and CNP potently stimulates cGMP accumulation in rat pituitary cell cultures and pituitary cell lines. The mouse gonadotroph-derived $\alpha \mathrm{T} 3-1$ cell line has been shown to express CNP as well as GC-B (but not GC-A) receptors, suggesting that CNP may well be an autocrine regulator of gonadotrophs. Comparing effects of three natriuretic peptides (atrial natriuretic peptide (ANP), B-type natriuretic peptide (BNP) and CNP) on cGMP accumulation in four pituitary cell lines $\left(\alpha \mathrm{T} 3-1\right.$, TtT-GF, AtT-20 and $\left.\mathrm{GH}_{3}\right)$ we find that CNP is most potent and effective in $\alpha \mathrm{T} 3-1$ cells. In these cells, CNP-stimulated cGMP accumulation was found to desensitise during a $30 \mathrm{~min}$ exposure to CNP.
\end{abstract}

Pretreatment with CNP for up to $6 \mathrm{~h}$ also caused a significant reduction in the ability of CNP to subsequently stimulate cGMP accumulation. This effect was receptor specific, because pretreatment with sodium nitroprusside (an activator of nitric oxide-sensitive guanylyl cyclase), or with ANP or BNP, did not cause desensitisation of CNP-stimulated cGMP accumulation. Protein kinase C activation with phorbol esters also inhibited CNPstimulated cGMP accumulation and such inhibition was also seen in cells desensitised by pretreatment with CNP. Thus it appears that the endogenous GC-B receptors of $\alpha \mathrm{T} 3-1$ cells are subject to both homologous and heterologous desensitisation, that the mechanisms underlying these forms of desensitisation are distinct, and that cGMP elevation alone is insufficient to desensitise GC-B receptors.

Journal of Endocrinology (2000) 166, 195-203

\section{Introduction}

The natriuretic peptides atrial natriuretic peptide (ANP), B-type natriuretic peptide (BNP) and C-type natriuretic peptide (CNP) act via their specific guanylyl cyclasecontaining receptors to stimulate cGMP accumulation. ANP and BNP exert well-documented effects on haemodynamic and cardiovascular regulation (Samson 1992, Wilkins et al. 1993). Of the three peptides, CNP has the lesser role in these pathways, and the finding that its highest tissue concentration is in the anterior pituitary suggests that it may perform regulatory roles alternative to those described for ANP and BNP (Komatsu et al. 1991). In rats and mice, CNP is localised in luteinising hormonepositive cells of the anterior pituitary (McArdle et al. 1994b). Previous studies in $\alpha$ T3-1 cells have shown that gonadotrophin-releasing hormone $(\mathrm{GnRH})$, an important regulator of gonadotrophs and an essential regulator of reproductive function, can inhibit CNP-stimulated cGMP accumulation (McArdle et al. 1993). However, CNP has recently been shown to inhibit GnRH-stimulated calcium mobilisation, suggesting that a reciprocal regulatory pathway exists between CNP and GnRH (Fowkes et al. 1999).

The majority of natriuretic peptide effects are exerted via their guanylyl cyclase receptors, namely GC-A and GC-B (Chang et al. 1989, Chinkers et al. 1989, Garbers 1989). These single transmembrane-region proteins contain intrinsic guanylyl cyclase, and share homology with the family of growth factor receptors, although they have not been shown to exert kinase activity (Chinkers et al. 1989, Drewett \& Garbers 1994). ANP and BNP preferentially bind to and stimulate the GC-A receptor, whereas CNP is considerably more effective than ANP or BNP at activating the GC-B receptor (Suga et al. 1992). These receptors are expressed in almost all tissues of the body, and many anterior pituitary cell types are known to express one or both receptors (Gutkowska \& Nemer 1989, AnandSrivastava \& Trachte 1993, Grandclément et al. 1995). 
However, there is conflicting evidence, based on a number of studies, as to which natriuretic peptide GC receptor is predominant in anterior pituitary cells, due mostly to the diverse range of techniques utilised (Kurihara et al. 1987, Koch et al. 1988, Wilcox et al. 1991, Konrad et al. 1992, Tallerico-Melnyk et al. 1992, McArdle et al. 1993, 1994a,b, Gilkes et al. 1994a, Shimekake et al. 1994, Grandclément et al. 1995, Langub et al. 1995, Guild \& Cramb 1999).

Regulation of natriuretic peptide-stimulated cGMP accumulation has been studied over recent years (Potter \& Garbers 1992, 1994, McArdle et al. 1993, Potter 1998). Previous studies, using cells transfected with either GC-A or GC-B receptors, have revealed that these receptors exist as phosphoproteins (predominantly serine/threonine residues) when inactive (Potter \& Garbers 1994, Potter \& Hunter 1998). Prolonged activation by the respective ligand (ANP or $\mathrm{CNP}$ ) can cause dephosphorylation of these residues, resulting in homologous desensitisation of the transfected receptors (Potter \& Garbers 1994, Potter 1998). In addition, activators of protein kinase $\mathrm{C}$ (PKC), such as 12-phorbol, 13-myristate acetate (PMA) and GnRH have been shown to inhibit natriuretic peptide-stimulated cGMP accumulation in a number of tissues, in a receptor-specific manner (McArdle et al. 1993, 1994a, Yeung et al. 1992, Gilkes et al. 1994a, Potter \& Garbers 1994, Paulding \& Sumners 1996). We have shown that the GC-B receptors of $\alpha \mathrm{T} 3-1$ cells are subject to heterologous regulation (inhibition by $\mathrm{GnRH}$ and phorbol esters) (McArdle et al. 1994a) but homologous regulation of endogenous GC-B has not yet been reported.

In addition to CNP, gonadotrophs also express the enzyme responsible for the generation of nitric oxide (NO), NO synthase (NOS) (Ceccatelli et al. 1993). NO has also been shown to activate the cGMP signalling pathway, by interacting with the ligand-binding domain of intracellular (soluble) guanylyl cyclase receptors (Drewett \& Garbers 1994, Wedel \& Garbers 1998). As gonadotrophs are known to express NOS, soluble guanylyl cyclase, CNP and GC-B receptors, this predisposes them to be important regulators of cGMP signalling within the anterior pituitary (Ceccatelli et al. 1993, McArdle et al. 1993, Garrel et al. 1998).

By comparing responses to three natriuretic peptides in four pituitary cell lines, we provide evidence here that $\mathrm{GC}-\mathrm{B}$ receptors in gonadotrophs are the major targets for natriuretic peptide action in the anterior pituitary. We also show that these receptors undergo homologous as well as heterologous desensitisation, and that these effects are additive, implying that distinct mechanisms underlie these two forms of modulation.

\section{Materials and Methods}

\section{Materials}

Culture medium and supplements were from Gibco BRL (Paisley, Strathclyde, UK) and rat ANP (residues 99-126), rat BNP (32 residues) and porcine CNP (22 residues) were purchased from Peninsula Laboratories (Merseyside, $\mathrm{UK}$ ). Sodium nitroprusside (SNP, an activator of the NO-sensitive soluble guanylyl cyclase), isobutyl methylxanthine (IBMX), PMA and synthetic CNP were all purchased from Sigma Chemical Co. (Poole, Dorset, UK). aT3-1 cells (Windle et al. 1990) were kindly provided by Prof. P Mellon (University of California San Diego, Department of Reproductive Medicine, La Jolla, CA, USA). All other reagents were from standard commercial suppliers.

\section{Cell culture}

aT3-1, TtT-GF (Inoue et al. 1992) and AtT-20 cells were maintained in Dulbecco's modified Eagle's medium with $2 \mathrm{mM}$ glutamine, $100 \mathrm{IU} / \mathrm{ml}$ penicillin, $100 \mu \mathrm{g} / \mathrm{ml}$ streptomycin, $10 \%$ (v/v) foetal calf serum (FCS) and $2 \cdot 5 \%$ $(\mathrm{v} / \mathrm{v})$ horse serum (HS) (culture medium) under a watersaturated atmosphere containing $5 \%(\mathrm{v} / \mathrm{v}) \mathrm{CO}_{2}$ in air at $37^{\circ} \mathrm{C} . \mathrm{GH}_{3}$ cells were cultured in similar medium, but supplemented with 5\% FCS, 5\% HS. Cells were cultured in T25 and T75 flasks (Nunc, Life Technologies, Paisley, UK) and were passaged at 7 day intervals as described previously (McArdle et al. 1993, 1994a). In preparation for experiments, the cells were harvested by trypsinisation then incubated in 24-well plates (Falcon, Life Technologies, Paisley, UK), or until they reached approximately $70 \%$ confluence. Variability was seen in the responsiveness of the cells from experiment to experiment. Therefore, normalisation was performed on data from the same cells from the same experimental day. The DNA content of cells was determined as required using a fluorescence microplate assay, by comparison of a standard curve of calf thymus DNA, ranging from 0.39 to $100 \mu \mathrm{g} / \mathrm{ml}$ and $25 \mu \mathrm{l}$ of $4 \mu \mathrm{g} / \mathrm{ml}$ bisbenzamidazole (Hoescht 33258, BDH, Poole, UK), according to the manufacturer's instructions.

\section{Natriuretic peptide stimulation of cGMP accumulation}

Cells were washed before use in a physiological salt solution (PSS: $127 \mathrm{mM} \mathrm{NaCl}, 1.8 \mathrm{mM} \mathrm{CaCl}_{2}, 5 \mathrm{mM} \mathrm{KCl}$, $2 \mathrm{mM} \mathrm{MgCl}, 0.5 \mathrm{mM} \mathrm{NaH} \mathrm{PO}_{4}, 5 \mathrm{mM} \mathrm{NaHCO}$, $10 \mathrm{mM}$ glucose, $0 \cdot 1 \%(\mathrm{w} / \mathrm{v}) \mathrm{BSA}$, and $10 \mathrm{mM}$ Hepes, at $\mathrm{pH} 7 \cdot 4$ ) at $37^{\circ} \mathrm{C}$. Any pretreatments were conducted in PSS without the non-specific phosphodiesterase inhibitor, IBMX. Before stimulation, pretreatments were removed and the cells were again washed with PSS at $37^{\circ} \mathrm{C}$. The cells were stimulated with $250 \mu \mathrm{l}$ PSS containing $10^{-3} \mathrm{M}$ IBMX and the indicated stimuli. The stimulations were terminated by the addition of $750 \mu 1100 \%$ ethanol at $-20{ }^{\circ} \mathrm{C}$. The plates were kept at $-20{ }^{\circ} \mathrm{C}$ for at least $1 \mathrm{~h}$ before centrifugation at $250 \mathrm{~g}$, at $4{ }^{\circ} \mathrm{C}$ for $10 \mathrm{~min}$. The supernatants were collected, vacuum dried under heat $\left(60^{\circ} \mathrm{C}\right)$ and reconstituted with $500 \mu$ lassay buffer (Medium 199, $10 \mathrm{mM}$ Hepes ( $\mathrm{pH} 7 \cdot 4$ ), 0.05\% (w/v) 
Table 1 The magnitude of CNP- and SNP-stimulated cGMP accumulation varies between the anterior pituitary-derived cell lines. Responses of cells to $10^{-6} \mathrm{M} \mathrm{CNP}$ and $10^{-3} \mathrm{M}$ $\mathrm{SNP}$ in the presence of $10^{-3} \mathrm{M} \mathrm{IBMX}$ for $15 \mathrm{~min}(\mathrm{pmol} / \mu \mathrm{g}$ DNA, means \pm S.E.M., $n=3$ )

\begin{tabular}{|c|c|c|c|c|}
\hline & \multicolumn{4}{|l|}{ Cell line } \\
\hline & $\alpha \mathrm{T} 3-1$ & $\mathrm{GH}_{3}$ & TtT-GF & AtT-20 \\
\hline Response to $10^{-6} \mathrm{M} \mathrm{CNP}$ & $9 \cdot 2 \pm 1 \cdot 9^{* *}$ & $2 \cdot 6 \pm 0 \cdot 4$ & $1 \cdot 1 \pm 0 \cdot 1$ & $0 \cdot 8 \pm 0 \cdot 1$ \\
\hline Response to $10^{-3} \mathrm{M} \mathrm{SNP}$ & $5 \cdot 6 \pm 0 \cdot 9 * * *$ & $0 \cdot 02 \pm 0.004$ & $0 \cdot 02 \pm 0 \cdot 009$ & $1 \cdot 2 \pm 0 \cdot 1$ \\
\hline
\end{tabular}

sodium azide). These samples were stored at $-20{ }^{\circ} \mathrm{C}$ to await assay for cGMP content.

\section{Iodination, purification and RIA of cGMP}

Ethanol extracted cGMP was measured by RIA as described previously (McArdle et al. 1993). ${ }^{125}$ I-cGMPtyrosylmethyl ester (TME) was prepared from cGMPTME and $\left[{ }^{125} \mathrm{I}\right] \mathrm{NaI}$ by the chloramine-T method (Hunter \& Greenwood 1962), and purified by column gel filtration. The range of the standard curve was from 0.042 to $25 \mathrm{pmol} / 100 \mu \mathrm{l}$, and cGMP antisera, provided by Dr M Schumacher (Institute for Hormone and Fertility Research, University of Hamburg, Germany) was used at 1:480 000 final dilution. Bound ${ }^{125} \mathrm{I}-\mathrm{cGMP}$ was precipitated with 10\% (w/v) PBS, containing 16\% (w/v) PEG$6000,0 \cdot 1 \%(\mathrm{w} / \mathrm{v}) \mathrm{NaN}_{3}, 1 \%(\mathrm{v} / \mathrm{v})$ normal rabbit serum and $1 \%(\mathrm{v} / \mathrm{v})$ donkey anti-rabbit $\operatorname{IgG}$ (SAPU, Lanarkshire, $\mathrm{UK})$. After a $5 \mathrm{~min}$ incubation, the tubes were centrifuged for $15 \mathrm{~min}$ at $500 \mathrm{~g}$, at $4{ }^{\circ} \mathrm{C}$. The supernatants were decanted and the radioiodine in the resulting pellets was counted for 1 min in a Packard multiwell gamma counter. The inter-assay variation was approximately $8 \%$.

\section{Data presentation and statistical analysis}

The figures show data from multiple experiments and are reported as the mean \pm S.E.M. of $n$ independent observations, performed in triplicate on different days. In some instances, data are reported as a percentage of control response values, as indicated in the figure legends. Statistical analysis was by ANOVA followed by Student's $t$-test or Tukey's multiple comparisons test, accepting $P<0.05$ as statistically significant. All data shown were analysed and plotted using GraphPad Prism 2.01 and 3·0 (GraphPad, San Diego, CA, USA).

\section{Results}

Comparison of natriuretic peptide action in pituitary cell lines

Previous studies have revealed that natriuretic peptides stimulate cGMP accumulation in aT3-1 (McArdle et al. 1993, 1994a), AtT-20 (Gilkes et al. 1994b) and $\mathrm{GH}_{3}$ cells
(Hartt et al. 1995, McArdle et al. 1993), but there has been no internally controlled comparative study to establish the effectiveness of ANP, BNP and CNP in these cells lines. We have previously found CNP to stimulate cGMP accumulation in $\alpha \mathrm{T} 3-1$ cells with an approximate $\mathrm{EC}_{50}$ value of $5 \times 10^{-8} \mathrm{M}$ (McArdle et al. 1993, 1994a). Our preliminary studies investigating natriuretic peptide and SNP-stimulated cGMP accumulation in pituitary cell lines revealed that $\mathrm{CNP}$ was the most effective stimulator of cGMP accumulation in $\alpha \mathrm{T} 3-1$, TtT-GF and AtT-20 cells, and was as equally effective as ANP in $\mathrm{GH}_{3}$ cells (data not shown). SNP was only effective in $\alpha \mathrm{T} 3-1$ and AtT-20 cells (Table 1). A comparison of the effectiveness of CNP and SNP-stimulated cGMP accumulation in the four cell lines was facilitated by normalising cGMP accumulation per microgram DNA. This revealed that $\alpha \mathrm{T} 3-1$ cells produced significantly more cGMP in response to $10^{-6} \mathrm{M}$ CNP and $10^{-3} \mathrm{M}$ SNP than any other cell line $(P<0 \cdot 01$ and $P<0 \cdot 001$ respectively) (Table 1$)$.

\section{Homologous desensitisation of CNP-stimulated cGMP accumulation}

To establish whether CNP-stimulated cGMP accumulation was subject to homologous desensitisation, $\alpha \mathrm{T} 3-1$ cells were subjected to time-course treatments with $10^{-7} \mathrm{M}$ CNP in the presence of $10^{-3} \mathrm{M}$ IBMX. As shown (Fig. 1), the initial rate of cGMP accumulation was not maintained and the cGMP level reached a plateau after $10 \mathrm{~min}$.

\section{Effect of CNP pretreatment on CNP-stimulated cGMP accumulation}

To establish whether prolonged activation of the GC-B receptor resulted in an attenuated response to subsequent stimulation with CNP, $\alpha \mathrm{T} 3-1$ cells were pretreated for up to $6 \mathrm{~h}$ with PSS containing 0 or $10^{-7} \mathrm{M}$ CNP. Following a thorough wash with PSS, the cells were stimulated for 15 min with PSS containing $10^{-7} \mathrm{M} \mathrm{CNP}$, in the presence of IBMX (Fig. 2A). The CNP response in cells pretreated for 3 and $6 \mathrm{~h}$ was significantly reduced compared with non-pretreated cells (to $55 \cdot 4 \pm 8 \cdot 3$ and $42 \cdot 8 \pm 8 \cdot 3 \%$, $P<0 \cdot 05$ and $P<0 \cdot 01$ respectively). Having established that 


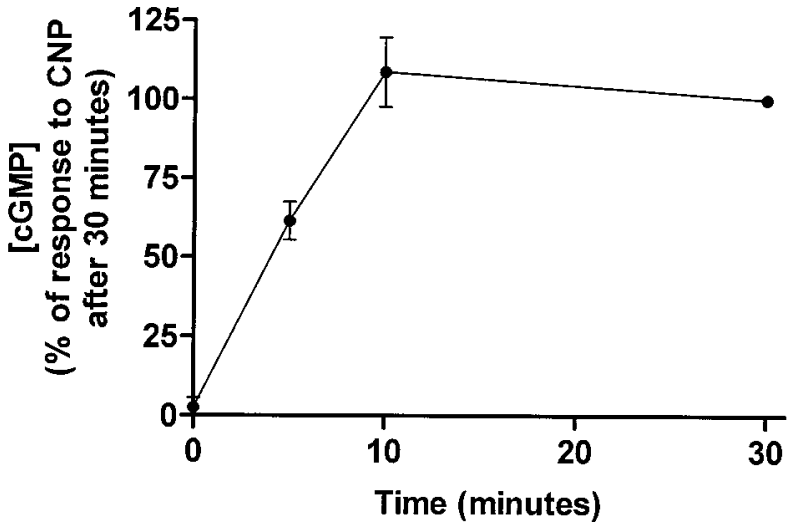

Figure 1 CNP-stimulated cGMP accumulation undergoes acute homologous desensitisation within $30 \mathrm{~min}$ in $\alpha \mathrm{T} 3-1$ cells. $\alpha \mathrm{T} 3-1$ cells were stimulated with PSS containing $10^{-7} \mathrm{M} \mathrm{CNP}$ in the presence of $10^{-3} \mathrm{M} I B M X$ for up to $30 \mathrm{~min}$. The time 0 value was obtained following the immediate addition of $-20{ }^{\circ} \mathrm{C} 100 \%$ ethanol following the administration of CNP. The concentration of cGMP accumulated after 10 min was not significantly different from that measured after $30 \mathrm{~min}(P>0.5)$. The data shown are the means \pm S.E.M. $(n=10)$, expressed as a percentage of the response to $10^{-7} \mathrm{M} \mathrm{CNP}$ at $30 \mathrm{~min}$, which ranged from approximately 65 to $82 \mathrm{pmol} / \mathrm{ml}$.

CNP pretreatment for up to $6 \mathrm{~h}$ could reduce the responsiveness of $\alpha \mathrm{T} 3-1$ cells to subsequent stimulation by CNP, an experiment was conducted to determine whether this effect was concentration dependent. $\alpha \mathrm{T} 3-1$ cells were pretreated for $6 \mathrm{~h}$ with PSS containing 0 or $10^{-9} \mathrm{M}$ to $10^{-6} \mathrm{M}$ CNP, before being washed and stimulated for 15 min with PSS containing $10^{-7} \mathrm{M} \mathrm{CNP}$, in the presence of IBMX (Fig. 2B). Pretreatment with $10^{-8} \mathrm{M}, 10^{-7} \mathrm{M}$ or $10^{-6} \mathrm{M} \mathrm{CNP}$ significantly reduced the response to subsequent CNP stimulation to $36 \cdot 2 \pm 13 \cdot 7,14 \cdot 9 \pm 5 \cdot 6$ and $20 \cdot 4 \pm 7 \cdot 5 \%$ compared with non-pretreated cells $(P<0 \cdot 05, P<0 \cdot 01$ and $P<0 \cdot 01$ respectively).

\section{Receptor specificity of CNP-dependent homologous} desensitisation

Previous studies have failed to detect any GC-A mRNA in $\alpha \mathrm{T} 3-1$ cells, suggesting that all natriuretic peptidestimulated cGMP accumulation occurs via the GC-B receptor (McArdle et al. 1994a). To test the receptor specificity of homologous desensitisation, $\alpha \mathrm{T} 3-1$ cells were pretreated for $6 \mathrm{~h}$ with PSS containing $0,10^{-7} \mathrm{M}$ ANP, $\mathrm{BNP}$ or CNP, or with $10^{-3} \mathrm{M}$ SNP, before subsequent stimulation with PSS containing $10^{-7} \mathrm{M}$ CNP for 15 min, in the presence of IBMX. ANP, BNP or SNP pretreatments failed to alter subsequent $\mathrm{CNP}$-stimulated cGMP accumulation, but CNP pretreatment caused the expected attenuation in the cGMP response to subsequent CNP stimulation to $30 \cdot 9 \pm 3.9 \%$ of control $(P<0 \cdot 01$, Fig. $3 \mathrm{~A})$. By means of comparison, $\alpha \mathrm{T} 3-1$ cells were again pretreated with ANP, BNP, CNP or SNP for $6 \mathrm{~h}$ but
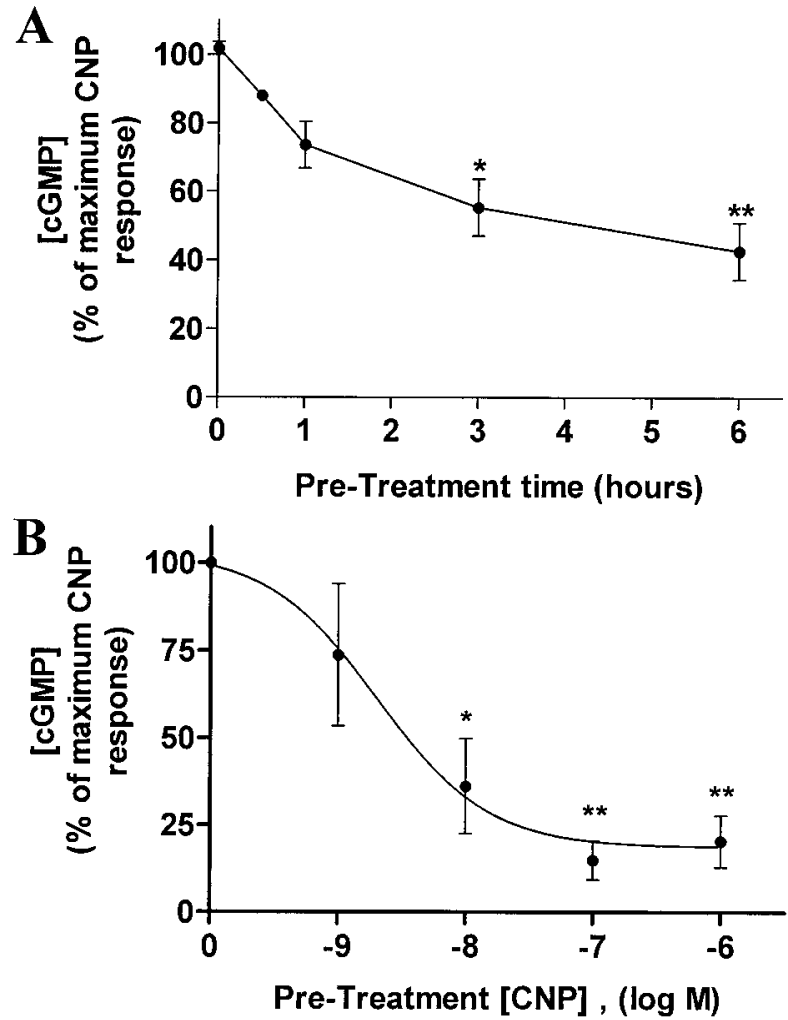

Figure 2 Time course and concentration dependence of chronic desensitisation of CNP-stimulated cGMP accumulation in $\alpha \mathrm{T} 3-1$ cells. (A) $\alpha \mathrm{T} 3-1$ cells were pretreated with PSS containing 0 or $10^{-7} \mathrm{M} \mathrm{CNP}$ for the indicated time periods, then washed and stimulated with $10^{-7} \mathrm{M}$ CNP in the presence of $10^{-3} \mathrm{M} \mathrm{IBMX}$ for $15 \mathrm{~min}$. Basal values for CGMP accumulation were subtracted as they were found not to differ. Following CNP pretreatment, the cGMP response to subsequent CNP stimulation was significantly reduced after 3 and $6 \mathrm{~h}$ pretreatment $\left({ }^{*} P<0 \cdot 05,{ }^{*} P<0 \cdot 01, n=3\right)$. The data shown are the means \pm S.E.M. of values expressed as a percentage of the internal control responses to CNP (which ranged from 68 to $86 \mathrm{pmol} / \mathrm{ml}, n=4-6$ ). (B) $\alpha \mathrm{T} 3-1$ cells were pretreated with PSS containing the indicated concentrations of CNP for $6 \mathrm{~h}$ before being washed and stimulated with $10^{-7} \mathrm{M}$ CNP in the presence of $10^{-3} \mathrm{M} I B M X$ for $15 \mathrm{~min}$. Pretreatment with $10^{-8}, 10^{-7} \mathrm{M}$ and $10^{-6} \mathrm{M}$ CNP reduced the cGMP response to subsequent CNP stimulation ( $\left.{ }^{*} P<0 \cdot 05,{ }^{* *} P<0 \cdot 01, n=3\right)$. The data shown are expressed as a percentage of the internal control response to CNP (which was approximately $200 \mathrm{pmol} / \mathrm{ml}$ ).

were then stimulated with $10^{-3} \mathrm{M}$ SNP for $15 \mathrm{~min}$. The natriuretic peptides failed to alter the response to SNP, but SNP-pretreated cells showed a significantly inhibited response to subsequent stimulation with SNP to $22 \cdot 7 \pm 2 \cdot 1 \%$ of control $(P<0 \cdot 05$, Fig. 3B).

\section{Effect of CNP pretreatment on GC-B concentration responsiveness to CNP}

To further investigate the apparent homologous desensitisation of CNP action in pretreated cells, a concentrationresponse curve to CNP was examined in cells that were 
CNP-stimulated cGMP accumulation

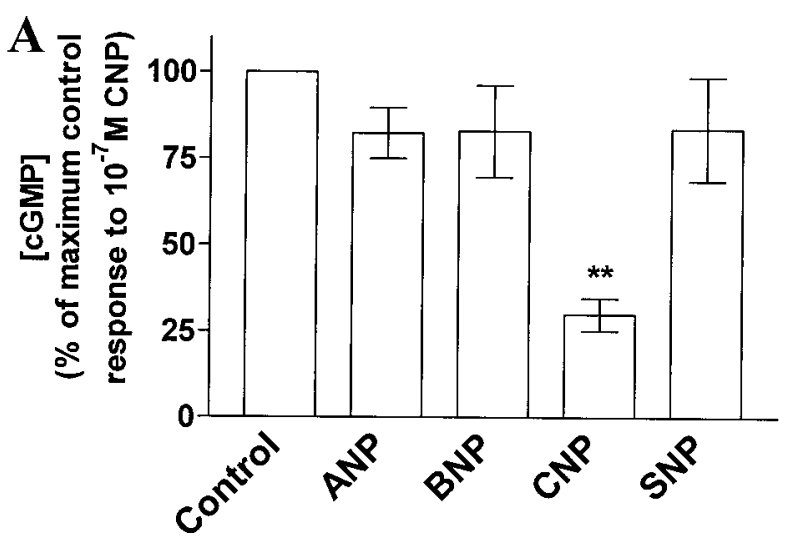

Pre-Treatment

SNP-stimulated cGMP accumulation

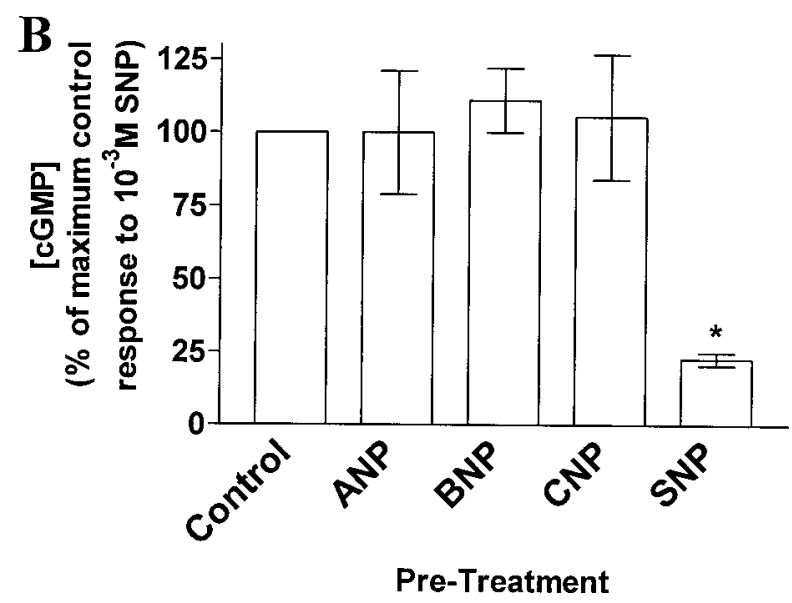

Figure 3 Homologous desensitisation of CNP and SNP-stimulated cGMP accumulation is ligand specific in $\alpha \mathrm{T} 3-1$ cells. (A) $\alpha \mathrm{T} 3-1$ cells were pretreated with PSS containing 0 or $10^{-7} \mathrm{M}$ ANP, BNP and CNP, or $10^{-3} \mathrm{M}$ SNP for $6 \mathrm{~h}$ before being washed and stimulated with $10^{-7} \mathrm{M} \mathrm{CNP}$ in the presence of $10^{-3} \mathrm{M} \mathrm{IBMX}$ for $15 \mathrm{~min}$. CNP pretreatment significantly reduced the subsequent response to CNP (**P<0.01,n=3), but ANP, BNP and SNP pretreatments had no such effects $(P>0 \cdot 5)$. The data shown are expressed as a percentage $( \pm$ S.E.M.) of the internal control response to CNP (which was approximately $70 \mathrm{pmol} / \mathrm{ml}$ ). (B) $\alpha \mathrm{T} 3-1$ cells were pretreated with PSS containing 0 or $10^{-7} \mathrm{M}$ ANP, BNP and CNP, or $10^{-3} \mathrm{M}$ SNP for $6 \mathrm{~h}$ before being washed and stimulated with $10^{-3} \mathrm{M}$ SNP in the presence of $10^{-3} \mathrm{M}$ IBMX for $15 \mathrm{~min}$. SNP pretreatment significantly reduced the subsequent response to SNP $\left({ }^{*} P<0 \cdot 05, n=3\right)$, but ANP, BNP and CNP pretreatments had no such effects $(P>0 \cdot 5)$. The data shown are expressed as a percentage ( \pm S.E.M.) of the internal control response to SNP (which was approximately $150 \mathrm{pmol} / \mathrm{ml}$ ).

pretreated with 0 or $10^{-7} \mathrm{M} \mathrm{CNP}$ for $6 \mathrm{~h}$ (Fig. 4). In both control and pretreated cells, subsequent stimulation with $10^{-8}, 10^{-7}$ and $10^{-6} \mathrm{M}$ CNP significantly stimulated cGMP accumulation above basal values. However,

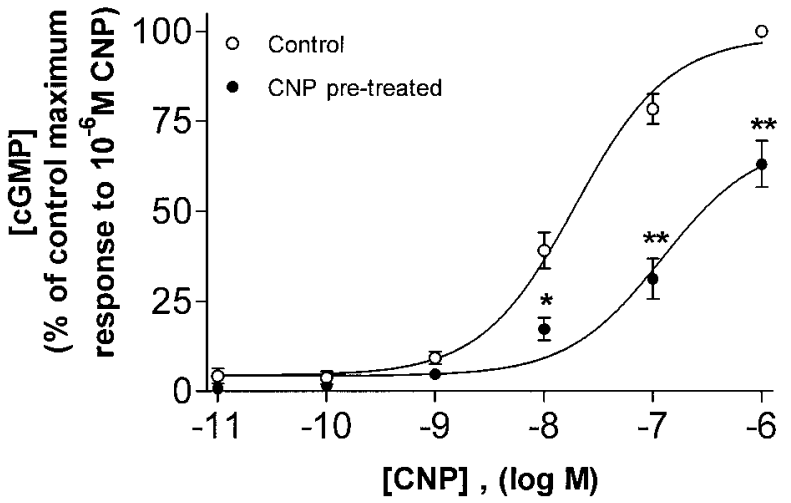

Figure 4 Effect of CNP pretreatment on concentration responsiveness to CNP in $\alpha \mathrm{T} 3-1$ cells. $\alpha \mathrm{T} 3-1$ cells were pretreated with PSS containing 0 or $10^{-7} \mathrm{MCNP}$ for $6 \mathrm{~h}$, then washed and stimulated with the indicated concentrations of CNP in the presence of $10^{-3} \mathrm{M}$ IBMX for $15 \mathrm{~min}$. The magnitude of the subsequent responses to $10^{-8}, 10^{-7}$ and $10^{-6} \mathrm{M} \mathrm{CNP}$ in CNP-pretreated cells were significantly attenuated compared with relevant control responses $\left({ }^{*} P<0 \cdot 05,{ }^{*} P<0 \cdot 01, n=5\right)$. The data shown are expressed as a percentage $( \pm$ S.E.M.) of the internal control response to $10^{-6} \mathrm{M} \mathrm{CNP}$ (which ranged from approximately 75 to $210 \mathrm{pmol} / \mathrm{ml}$ ).

pretreatment caused a significant reduction in the responses to subsequent stimulation with $10^{-8}, 10^{-7}$ and $10^{-6} \mathrm{M}$ CNP compared with similar responses in control cells $(P<0 \cdot 01$ and $P<0 \cdot 001)$.

Comparison of homologous and heterologous desensitisation of CNP-stimulated cGMP accumulation

Heterologous inhibition of CNP action by activators of PKC activity has previously been reported in $\alpha \mathrm{T} 3-1$ cells (McArdle et al. 1993, 1994a). To establish whether heterologous desensitisation of CNP action in $\alpha \mathrm{T} 3-1$ cells could occur even in cells desensitised to CNP by pretreatment, $\alpha \mathrm{T} 3-1$ cells were pretreated with either 0 or $10^{-7} \mathrm{M}$ CNP for $6 \mathrm{~h}$ prior to stimulation with $10^{-6} \mathrm{M}$ $\mathrm{CNP}$ concentrations for $15 \mathrm{~min}$ in the absence or presence of $10^{-7} \mathrm{M}$ PMA. CNP pretreatment significantly inhibited the cGMP response to $41 \cdot 7 \pm 6 \cdot 7 \%$ of control, but the presence of PMA further reduced CNP-stimulated cGMP accumulation in pretreated cells to $16 \cdot 4 \pm 6 \cdot 6$ and $12 \cdot 6 \pm 5 \cdot 1 \%$ of control (Fig. 5A). None of the treatments significantly affected SNP-stimulated cGMP accumulation (Fig. 5B).

\section{Discussion}

Many pituitary cell types have been shown to express natriuretic peptide receptors and to respond to natriuretic peptides, to stimulate cGMP accumulation (McArdle et al. 1993, 1994a, Gilkes et al. 1994b, Grandclément et al. 1995, 

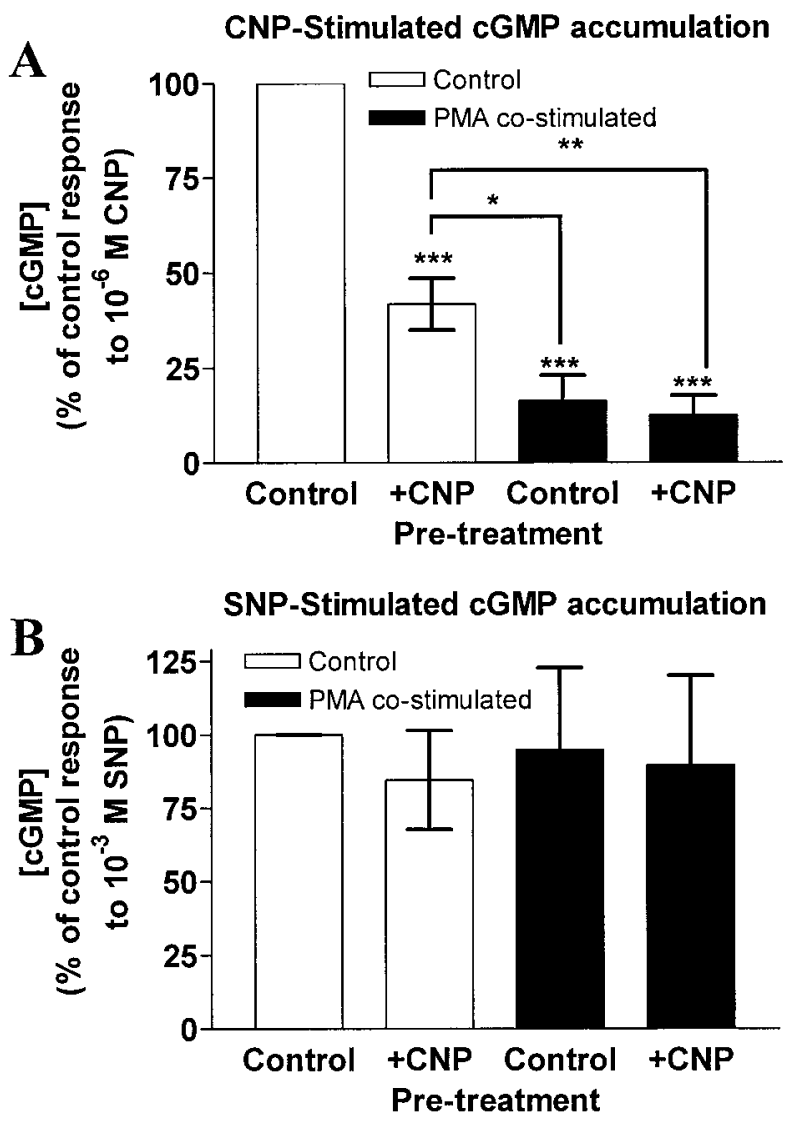

Figure 5 Homologous and heterologous desensitisation of CNPstimulated cGMP accumulation occur concurrently in $\alpha \mathrm{T} 3-1$ cells. (A) $\alpha \mathrm{T} 3-1$ cells were pretreated with PSS containing 0 or $10^{-7} \mathrm{M}$ $\mathrm{CNP}$ for $6 \mathrm{~h}$, then washed and stimulated with $10^{-6} \mathrm{M} \mathrm{CNP}$ and 0 or $10^{-7} \mathrm{M}$ PMA (co-stimulation) in the presence of $10^{-3} \mathrm{M}$ IBMX for $15 \mathrm{~min}$. The CGMP response to CNP in pretreated cells was significantly reduced compared with control cells ${ }^{* * *} P<0 \cdot 001$, $n=5)$. PMA-co-stimulated cells showed even greater inhibition than CNP-pretreated cells $\left({ }^{*} P<0 \cdot 05,{ }^{*} P<0 \cdot 01\right)$. However, there was no significant difference between PMA-co-stimulated control or CNP-pretreated cells $(P>0 \cdot 5)$. The data shown are expressed as a percentage ( \pm S.E.M.) of the internal control response to $10^{-6} \mathrm{M}$ CNP (which ranged from approximately 70 to $215 \mathrm{pmol} / \mathrm{ml}$ ). (B) $\alpha \mathrm{T} 3-1$ cells were pretreated with PSS containing 0 or $10^{-7} \mathrm{M}$ CNP for $6 \mathrm{~h}$, then washed and stimulated with $10^{-3} \mathrm{M}$ SNP and 0 or $10^{-7} \mathrm{M}$ PMA (co-stimulation) in the presence of $10^{-3}$ M IBMX for 15 min. Neither CNP pretreatment nor PMA co-stimulation significantly affected SNP-stimulated cGMP accumulation $(P>0 \cdot 5, n=5)$. The data shown are expressed as a percentage $\left( \pm\right.$ S.E.M.) of the internal control response to $10^{-3} \mathrm{M}$ SNP (which ranged from approximately 30 to $75 \mathrm{pmol} / \mathrm{ml}$ ).

Guild \& Cramb 1999). Using four pituitary cell lines, we have determined the effectiveness of the natriuretic peptides at stimulating cGMP accumulation in each cell type. We established that CNP is the most potent natriuretic peptide in $\alpha \mathrm{T} 3-1$, TtT-GF and AtT-20 cells, and is as equipotent as ANP in $\mathrm{GH}_{3}$ cells. Furthermore, the concentration of cGMP produced in response to CNP in $\alpha \mathrm{T} 3-1$ cells was significantly greater than that seen in the other pituitary cell lines. Although the current data were derived from anterior pituitary cell lines, they complement previous studies which showed that CNP-stimulated cGMP accumulation in heterogeneous populations of rat pituitary cells was inhibited by greater than $50 \%$ following gonadotroph ablation (McArdle et al. 1994b). Taken together, these data support the hypothesis that gonadotrophs are the major target cell type for CNP action in the pituitary.

As well as assessing the potency of the natriuretic peptides in these pituitary cell lines, the ability of the NO donor, SNP, to stimulate cGMP accumulation in these cells was also investigated. NO can activate the intracellular (soluble) guanylyl cyclases to produce cGMP, a mechanism by which NO exerts many of its biological effects (Drewett \& Garbers 1994, Wedel \& Garbers 1998). However, only $\alpha \mathrm{T} 3-1$ and AtT-20 cells responded to SNP, suggesting that these cells express functional soluble guanylyl cyclase receptors. The finding that TtT-GF cells did not respond to SNP is interesting, as folliculo-stellate cells, along with gonadotrophs, are thought to be the only anterior pituitary cell types to express NOS, and therefore NO (Ceccatelli et al. 1993). The inability of an NO donor to stimulate cGMP in these cells suggests that the NO produced in folliculo-stellate cells acts as a paracrine regulator of other pituitary cell types or that $\mathrm{NO}$ autocrine effects on folliculo-stellate cells are mediated via target proteins other than GC.

The major aim of the current study was to establish whether endogenously expressed GC-B receptors in $\alpha \mathrm{T} 3-1$ cells are subject to homologous as well as heterologous desensitisation, as desensitisation can be dependent upon the context of receptor expression and receptor number. Considerable evidence exists for the homologous and heterologous desensitisation of the ANP-specific, GC-A receptor (Potter \& Garbers 1992, 1994). However, until recently, regulation of CNP action and particularly of the GC-B receptor had not been widely understood. Potter \& Hunter (1998) showed that in HEK293 cells transfected with GC-B receptor cDNA, the receptor exists in a phosphorylated state when unstimulated, in common with the GC-A receptor (Potter \& Garbers 1992, 1994). Following prolonged stimulation with CNP, GC-B receptors overexpressed in NIH3T3 cells appear to undergo homologous desensitisation due to the dephosphorylation of specific serine/threonine residues, which is manifested by a reduced ability of CNP to stimulate cGMP accumulation (Potter 1998).

To further establish how CNP action might be regulated in $\alpha \mathrm{T} 3-1$ cells, we pretreated $\alpha \mathrm{T} 3-1$ cells with CNP and other stimulators of cGMP accumulation in these cells, for up to $6 \mathrm{~h}$ to determine the effect on cGMP generation following subsequent treatment with CNP in the presence of the phosphodiesterase inhibitor, IBMX. We have shown that CNP-stimulated cGMP accumulation, 
mediated via endogenously expressed GC-B receptors in aT3-1 cells, is subject to both chronic and acute homologous desensitisation following prolonged exposure to CNP, and that elevated cGMP concentrations are not the sole regulatory mechanism for these observations.

aT3-1 cells stimulated for up to $30 \mathrm{~min}$ with $\mathrm{CNP}$ failed to maintain the initial rate of cGMP accumulation, even in the presence of a maximally effective dose of IBMX. This suggests that the GC-B receptor undergoes rapid homologous desensitisation within the first 10-30 min of activation by CNP. This decline in the rate of cGMP formation is unlikely to be caused by an increase in phosphodiesterase activity as neither ANP, BNP nor SNP affected CNP-stimulated cGMP accumulation, although these treatments can stimulate cGMP accumulation to varying degrees in $\alpha \mathrm{T} 3-1$ cells (McArdle et al. 1993, 1994a). Furthermore, activators of cAMP accumulation in $\alpha \mathrm{T} 3-1$ cells such as pituitary adenylate cyclase-activating polypeptide or forskolin, also fail to affect CNP-stimulated cGMP accumulation, yet these treatments would be expected to elevate cyclic nucleotide phosphodiesterase activity in these cells (McArdle et al. 1993, R C Fowkes \& C A McArdle, unpublished observations).

The decline in the rate of cGMP accumulation after $10 \mathrm{~min}$ is in agreement with the recently published data on the dephosphorylation and desensitisation of overexpressed GC-B receptors by CNP (Potter 1998) in NIH3T3 cells. However, Potter \& Garbers (1994) have shown that prolonged treatment $(>1 \mathrm{~h})$ with ANP leads to loss of transfected GC-A receptor protein. Therefore, the current observations in $\alpha \mathrm{T} 3-1$ cells pretreated for $6 \mathrm{~h}$ are potentially due to a combination of receptor desensitisation and receptor loss. The mechanisms for the currently observed effects on GC-B receptors are not known at present. However, what is intriguing about the homologous desensitisation of the GC-B receptor by CNP in $\alpha \mathrm{T} 3-1$ cells is that the phenomenon cannot be explained purely by the prolonged accumulation of cGMP in these cells. Neither SNP, ANP nor BNP pretreatments significantly affected CNP-stimulated cGMP accumulation (Fig. 3A), yet SNP significantly stimulates cGMP accumulation in $\alpha \mathrm{T} 3-1$ cells (see Table 1), and ANP and BNP can also cause significant elevations in cGMP accumulation in these cells, albeit at micromolar concentrations (McArdle et al. 1993, 1994a). Thus cGMP elevation alone is insufficient to cause GC-B desensitisation, although it is possible that desensitisation requires elevation of cGMP to activate proteins that act specifically on the active conformation of the receptor. This has been suggested to be the case for the GC-A receptor, where the presence of ANP at the GC-A receptor is needed in order for the receptor to undergo desensitisation (Potter \& Garbers 1994).

In all experiments, the NO donor SNP was used as a comparative treatment. It was interesting to note that pretreatment of $\alpha \mathrm{T} 3-1$ cells with SNP caused marked homologous down-regulation of cGMP accumulation in response to subsequent stimulation with SNP. In fact, the inhibition of the cGMP response in these pretreated cells was even more pronounced than the parallel observation seen in CNP-pretreated cells in response to CNP $(\sim 15 \%$ of control compared with $\sim 30 \%$ of control respectively). Desensitisation of soluble guanylyl cyclase, or effects similar to such a phenomenon, have been observed in other cells (Zhang et al. 1993, Ujiie et al. 1994). However, this study is the first to report such regulation in anterior pituitary-derived cells. Furthermore, these previous studies showed that the desensitisation of the soluble guanylyl cyclase by SNP could be mimicked by treatment with ANP or cell-permeable cGMP analogues (Zhang et al. 1993), and in vascular smooth muscle cells SNP pretreatment significantly increased subsequent ANPstimulated cGMP accumulation (Ujiie et al. 1994). This is in contrast with the results of the current study in which none of the natriuretic peptides were able to inhibit subsequent SNP-stimulated cGMP accumulation, suggesting that distinct mechanisms for the desensitisation of soluble guanylyl cyclases exist in $\alpha \mathrm{T} 3-1$ cells.

Previous studies have shown that activators of PKC (e.g. PMA, GnRH) are able to attenuate CNP-stimulated cGMP accumulation (McArdle et al. 1993, 1994a, Yeung et al. 1992) without affecting the NO-sensitive guanylyl cyclase (McArdle et al. 1993, 1994a), suggesting that the PKC effect is receptor specific. A similar phenomenon has been observed in cells expressing the ANP-specific GC-A receptor, where PKC activity leads to the dephosphorylation of the GC-A receptor and desensitises it to subsequent stimulation by ANP (Potter \& Garbers 1994). In the current study we have compared the extent to which CNP pretreatment and PMA co-stimulation cause homologous and heterologous desensitisation of CNPstimulated cGMP accumulation, reasoning that an additive effect would suggest distinct mechanisms. The major finding from these experiments was that PMA was able to significantly reduce CNP-stimulated cGMP accumulation even in CNP-pretreated cells (see Fig. 5A). In contrast, neither pretreatment with CNP nor co-stimulation with PMA was able to affect SNP-stimulated cGMP accumulation (Fig. 5B). This suggests that the mechanisms responsible for $\mathrm{CNP}-$ dependent and $\mathrm{PKC}$-dependent desensitisation of GC-B receptors are distinct, although they may both involve receptor dephosphorylation (Potter \& Garbers 1994).

In summary we have shown that CNP is a more efficient stimulus for cGMP accumulation in $\alpha \mathrm{T} 3-1$ cells than in $\mathrm{GH}_{3}$, TtT-GF or AtT-20 cells. Taken together with the fact that gonadotrophs express CNP, NOS, GC-B and soluble GC (Ceccatelli et al. 1993, McArdle et al. 1993, 1994a,b) these data support the notion that cGMP levels in gonadotrophs are controlled by autocrine and/or paracrine regulation of both soluble and particulate GCs. We also show, for the first time, that cGMP accumulation mediated by endogenous GC-B receptors 
can be subject to both homologous and heterologous desensitisation and that the mechanisms underlying these forms of desensitisation are likely to differ. Nevertheless, the physiological role(s) played by cGMP in gonadotrophs are essentially unknown and the relevance of these novel forms of regulation remains equally enigmatic.

\section{Acknowledgements}

The authors wish to thank Prof. P Mellon for the kind gift of the $\alpha \mathrm{T} 3-1$ cells, Dr M Schumacher for provision of the cGMP antisera for use in the cGMP RIA, and $\mathrm{Mr}$ $\mathrm{B}$ Williams for practical assistance. This work was generously funded by a studentship awarded to R C F by the Needham Cooper Fellowship. Finally, R C F acknowledges the support and assistance given by Prof. S L Lightman, and thanks Prof. J M Burrin and Prof. A J Clarke for their constructive comments during the preparation of this manuscript.

\section{References}

Anand-Srivastava MB \& Trachte GJ 1993 Atrial natriuretic factor receptors and signal transduction mechanisms. Pharmacological Reviews 45 455-497.

Ceccatelli S, Hulting A-L, Zhang X, Gustafsson L, Villar M \& Hokfelt T 1993 Nitric oxide synthase in the rat anterior pituitary gland and the role of nitric oxide in regulation of luteinizing hormone secretion. PNAS 90 11292-11296.

Chang M-S, Lowe DG, Lewis M, Hellmiss R, Chen E \& Goeddel DV 1989 Differential activation by atrial and brain natriuretic peptides of two different receptor guanylate cyclases. Nature $\mathbf{3 4 1}$ 68-72.

Chinkers M, Garbers DL, Chang M-S, Lowe DG, Chin H, Goeddel DV \& Schulz S 1989 A membrane form of guanylate cyclase is an atrial natriuretic peptide receptor. Nature 338 78-83.

Drewett JG \& Garbers DL 1994 The family of guanylyl cyclase receptors and their ligands. Endocrine Reviews 15 135-162.

Fowkes RC, Forrest-Owen W, Williams B \& McArdle CA 1999 Effects of C-type natriuretic peptide (CNP) on intracellular calcium $\left[\mathrm{Ca}^{2+}\right]_{\mathrm{i}}$ signaling in mouse gonadotrope-derived $\alpha \mathrm{T} 3-1$ cell line. Regulatory Peptides 84 43-49.

Garbers DL 1989 Guanylate cyclase, a cell surface receptor. Journal of Biological Chemistry 264 9103-9106.

Garrel G, Lerrant Y, Siriostis C, Bérault A, Magre S, Bouchard C \& Counis R 1998 Evidence that gonadotropin-releasing hormone stimulates gene expression and levels of active nitric oxide synthase type I in pituitary gonadotrophs, a process altered by desensitization and, indirectly, by gonadal steroids. Endocrinology 139 2163-2170.

Gilkes AF, Guild SB \& Cramb G 1994a Phorbol ester activation of protein kinase $\mathrm{C}$ inhibits CNP-stimulated cyclic GMP production in the mouse AtT-20 pituitary tumour cell line. Biochemical and Biophysical Research Communications 204 1318-1324.

Gilkes AF, Ogden PH, Guild SB \& Cramb G 1994b Characterization of natriuretic peptide receptor subtypes in the AtT-20 pituitary tumour cell line. Biochemistry Journal 299 481-487.

Grandclément B, Brisson C, Bayard F, Tremblay J, Gossard F \& Morel G 1995 Localization of mRNA coding for the three subtypes of atrial natriuretic factor (ANF) receptors in rat anterior pituitary gland cells. Journal of Neuroendocrinology 7 939-948.
Guild SB \& Cramb G 1999 Characterisation of the effects of natriuretic peptides upon ACTH secretion from the mouse pituitary. Molecular and Cellular Endocrinology 152 11-19.

Gutkowska J \& Nemer M 1989 Structure, expression, and function of atrial natriuretic factor in extraatrial tissue. Endocrine Reviews $\mathbf{1 0}$ $519-536$.

Hartt DJ, Ogiwara T, Ho AK \& Chik CL 1995 Cyclic GMP stimulated growth hormone release in rat anterior pituitary cells. Biochemical and Biophysical Research Communications 214 918-926.

Hunter WM \& Greenwood FC 1962 Preparation of iodine 131-labelled growth hormone of high specific activity. Nature 194 495-496.

Inoue K, Matsumoto H, Koyama C, Shibata K, Nakazato Y \& Ito A 1992 Establishment of a folliculo-stellate-like cell line from a murine thyrotropic pituitary tumour. Endocrinology 131 3110-3116.

Koch B, Boudjada T \& Lutz-Bucher B 1988 Characterization of high affinity receptor sites for atrial natriuretic factor in anterior pituitary gland: evidence for the existence of two receptor forms. Biochemical and Biophysical Research Communications 152 904-909.

Komatsu Y, Nakao K, Suga S, Ogawa Y, Mukoyama M, Arai H, Shirakami G, Hosoda K, Nakagawa O, Hama N, Kishimoto I \& Imura H 1991 C-type natriuretic peptide (CNP) in rats and humans. Endocrinology 129 1104-1106.

Konrad EM, Thibault G \& Schriffen EL 1992 Autoradiographic visualization of the natriuretic peptide receptor-B in rat tissues. Regulatory Peptides 39 177-189.

Kurihara M, Saavedra JM \& Shigematsu K 1987 Localization and characterization of atrial natriuretic peptide binding sites in discrete areas of rat brain and pituitary gland by quantitative autoradiography. Brain Research 408 31-39.

Langub MC Jr, Dolgas CM, Watson RE Jr \& Herman JP 1995 The $\mathrm{C}$-type natriuretic peptide receptor is the predominant natriuretic peptide receptor mRNA expressed in rat hypothalamus. Journal of Neuroendocrinology 7 305-309.

McArdle CA, Poch A \& Käppler K 1993 Cyclic guanosine monophosphate production in the pituitary: stimulation by C-type natriuretic peptide and inhibition by gonadotropin-releasing hormone in $\alpha \mathrm{T} 3-1$ cells. Endocrinology 132 2065-2072.

McArdle CA, Ivell R, Käppler K, Müller D, Schmidt C, Poch A \& Kratmeier M 1994a Production and action of C-type natriuretic peptide in the gonadotrope-derived $\alpha \mathrm{T} 3-1$ cell line. Endocrine 2 849-856.

McArdle CA, Olcese J, Schmidt C, Poch A, Kratzmeier M \& Middendorf R $1994 b$ C-type natriuretic peptide (CNP) in the pituitary: is CNP an autocrine regulator of gonadotropes? Endocrinology 135 2794-2801.

Paulding WR \& Sumners C 1996 Protein kinase C modulates natriuretic peptide receptors in astroglial cultures from rat brain. American Journal of Physiology 270 c740-c747.

Potter LR 1998 Phosphorylation-dependent regulation of the guanylyl cyclase-linked natriuretic peptide receptor B: dephosphorylation is a mechanism of desensitization. Biochemistry 37 2422-2429.

Potter LR \& Garbers DL 1992 Dephosphorylation of the guanylyl cyclase-A receptor causes desensitization. Journal of Biological Chemistry 267 14531-14534.

Potter LR \& Garbers DL 1994 Protein kinase C-dependent desensitization of the atrial natriuretic peptide receptor is mediated by dephosphorylation. Journal of Biological Chemistry 269 14636-14642.

Potter LR \& Hunter T 1998 Identification and characterization of the major phosphorylation sites of the B-type natriuretic peptide receptor. Journal of Biological Chemistry 273 15533-15539.

Samson WK 1992 Natriuretic peptides: a family of hormones. Trends in Endocrinology and Metabolism 3 86-90.

Shimekake Y, Ohta S \& Nagata K 1994 C-type natriuretic peptide stimulates secretion of growth hormone from rat pituitary-derived $\mathrm{GH}_{3}$ cells via a cyclic-GMP-mediated pathway. European Journal of Biochemistry 222 645-650. 
Suga S, Nakao K, Hosoda K, Mukoyama M, Ogawa Y, Shirakami G, Arai H, Saito Y, Kambayashi Y, Inouye K \& Imura H 1992 Receptor selectivity of natriuretic peptide family, atrial natriuretic peptide, brain natriuretic peptide, and C-type natriuretic peptide. Endocrinology 130 229-239.

Tallerico-Melnyk T, Yip CC \& Watt VM 1992 Widespread colocalisation of mRNAs encoding the guanylate cyclase-coupled natriuretic peptide receptors in rat tissues. Biochemical and Biophysical Research Communications 189 610-616.

Ujiie K, Hogarth L, Dnaziger R, Drewett JG, Yuen PST, Pang I-H \& Star RA 1994 Homologous and heterologous desensitization of a guanylyl cyclase-linked nitric oxide receptor in cultured rat medullary interstitial cells. Journal of Pharmacology and Experimental Therapeutics 270 761-767.

Wedel BJ \& Garbers DL 1998 Guanylyl cyclases: approaching year thirty. Trends in Endocrinology and Metabolism 9 213-219.

Wilcox JH, Augustine A \& Lowe DG 1991 Differential expression of three natriuretic peptide receptor genes within primate tissues. Molecular and Cellular Biology 11 3454-3462.
Wilkins MR, Nunez DJ \& Wharton J 1993 The natriuretic peptide family: turning hormones into drugs. Journal of Endocrinology 137 347-359.

Windle J, Weiner RI \& Mellon PL 1990 Cell lines of the pituitary gonadotrope lineage derived by targeted oncogenesis in transgenic mice. Molecular Endocrinology 4 597-603.

Yeung VTF, Ho SKS, Cockram CS, Lee CM \& Nicholls MG 1992 Activation of protein kinase $\mathrm{C}$ attenuates the cyclic GMP responses to $\mathrm{C}$-type natriuretic peptide in cultured mouse astrocytes. FEBS Letters 308 301-304.

Zhang LM, Castresana MR, Stefansson S \& Newman WH 1993 Tolerance to sodium nitroprusside - studies in cultured porcine vascular smooth muscle cells. Anaesthesiology 79 1094-1103.

Received 10 January 2000

Accepted 14 March 2000 